\title{
Trailing Appropriate Sustainable Development in Yasawa- Fiji Islands
}

\author{
Shobna Sabnam Hassan ${ }^{1}$, Krishne Gowda ${ }^{2}$ \\ ${ }^{I}$ Ph.D. Candidate at University of Mysore, Institute of Development Studies (IDS), University of Mysore, \\ Karnataka, India. \\ ${ }^{2}$ Director, School of Planning and Architecture, University of Mysore, Karnataka, India. \\ Corresponding Author: Shobna Sabnam Hassan
}

\begin{abstract}
This paper primarily studies the difference between development and sustainability prospects involving the people of Yasawa Island with initiatives of appropriate natural resource management. To achieve sustainability we seek to empower people to take decisions involving social, economic and environmental aspirations with a consistent and holistic approach. Sustainable development practices should be pursued in all facets of development activities. Today the environment is threatened by the impact of development activities coupled with increased population growth and land use activities. Emphasis should be self-determined and development integrated that enrich people while safeguarding the authenticity of environment for the population today and tomorrow. The objective of the paper is proper land use and management of resources integrated with holistic development prospects combined with participatory decision making. A need has emerged for more sustainable planning, policies, and programs that consider proper resource management as well as the needs of the local communities. Data mostly qualitative has been collected by means of literature review for this paper. The outcome of the study is to benefit the village people today and generations of tomorrow with better resource management addressing the threats to the resources. Success should not be solely measured in financial or economic terms, rather have a balance between traditional and business obligations.
\end{abstract}

Keywords: Development, Empower, Holistic, Sustainability, Resource Management, Fiji.

\section{Introduction}

People think that we have to make a choice between development and environmental protection however development that is sustainable is very much possible if we do not damage the flora and fauna. Development and environment should be mutually supportive. Holistically sustainable development is achievable if socially, economically and environmentally we are able to integrate these in a balanced way. In the past two decades, we have witnessed growing concern regarding depletion of many natural resources and deterioration in the quality of environmental resources due to unsustainable economic growth. Sustainable development must refer to a path of development that sustains something. According to the 1972 Stockholm United Nations Conference, the protection and improvement of the environment are the major factors that affect the well-being of people and economic development throughout the world. The questions are what is to be sustained and who is to decide? Important as well to note is the geographical isolation of South Pacific from major source markets which provides additional challenges for sustainability and development. According to the law of development of nature today virtually there are no resources which have not been intervened with human activity. As society becomes more concerned with natural resources which are evident at Yasawa Island, businesses and people modify their behavior to achieve sustainability in all aspects. Becoming socially responsible and protecting the economy from the potential future backlash. All available literature around sustainability acknowledges the high association between economy and environment. Any change in social values and behavior influence sustainability. It has also led some to conclude that sustainable development is oxymoron where development and sustainability cannot be reconciled. The quality of life has become increasingly important for government, academics and the general public. Hence to effectively manage limited resources we have to ensure equity in distribution and allow substantial time for the resources to replenish and find alternatives that guarantee sustainability. We believe we have a moral obligation to protect our fragile environment for future generations.

\section{Sustainable Growth and Development}

Development is synonymous with growth and often these two words are used arbitrarily. Development implies an overall improvement in qualitative and quantitative attributes and growth is the process of growing up quantitatively. There can be growth without development but not vice-versa. Sustainable development to be

DOI: 10.9790/5933-0804021115 www.iosrjournals.org $\quad 11 \mid$ Page


viable there has to be an economic growth an economic development policy based on sustainability should be one that ensures equal distribution of development to the society. The global community should feel the need for protecting the environment. Protection of the environment has become a global concern for all. Any development that destroys the environment destroys development in the long run.

\section{Indian Approach to Sustainable Development}

From the speech made by the late Prime Minister Indira Gandhi at the Stockholm Conference in 1972 was stated that the nation's concern for the environment and the need for sustainable development is clear. Improvements in the standards and quality of life of the people have to be based on the sustenance of life support systems through conservation and regeneration of the natural resource base. The present generation owes this not only to itself but also to future generations and to myriad other species with which its survival is linked. ". . . There should ' be more rigorous scrutiny of the environmental impact of every development scheme, and ecologically sustainable development accepted as an end in itself' (Ganguly 1996).

\section{Economic Development and Sustainable Development}

The world's resources are allocated to meet a few people's wants, not everyone's needs. Sustainable economic development is meant to be about efficient allocation of resources to meet everyone's needs. Structural alteration has opened up of economies rapidly, in socially, politically, environmentally and economically destructive ways. The people are encouraged to produce just a few cash crops and other commodities primarily for export, using very environmentally damaging "industrial agriculture", which reduces biodiversity, requiring costly inputs such as environmentally damaging products.

\section{Study Area}

Yasawa Island lies in the northwest corner of the Fijian archipelago. This long narrow island is roughly $20 \mathrm{~km}$ long and is $2 \mathrm{~km}$ wide being the driest island in Fiji. Yasawa Island is composed of 20 islands, sparsely populated with very few basic amenities on the main island with a population of 5000 people. The natural environment and pristine waters of the Yasawa Islands are the key draw card of our region. Over time, subsistence and settlement systems in the Yasawa Islands have changed. Sustainability issues arise when there is a risk or irreversible loss and whenever there is a risk action needs to be taken with urgency. Due to the remoteness and size of the island there are overwhelming challenges however with a clear understanding of the requirement of the current and future generation a better evolved and legitimate solution is achievable. The Yasawa were not always tourism oriented however after 1987 with the government's eco-tourism fund there are now small resorts and backpackers.

Yasawa Island epitomizes the attraction of an active tropical island which is composed of 20 islands, sparsely populated with very few basic amenities on the main island with a population of 5000 people mainly working on tourism and agricultural industry. The Fijian word "Mositi" connotes an attachment to something of value. It connotes a commitment to protect and manage the resources that are linked with people's livelihood and welfare. For indigenous Fijians, the relationship with the Vanua (land) is more than an economic relationship rather it is a spiritual association. The natural environment combined with the distinctive cultural heritage gives Yasawa Island an added advantage in the pursuit of tourism and development. However due to inadequate and inefficient proper development infrastructure becomes an obstacle. The government continues to provide a commercial environment that is stable for the future progress of the economy and raising public awareness on environmental issues and sustainability integrating with various private sector operators and NGO's.

\section{Problem Statement}

Sustainable development approaches are essential obligations hence the need for in-depth study of the various facets of sustainability. Given that development has often signaled as problematic and most efforts towards sustainable development goals were inadequate due to poor governance implementation. Common sense prevails that more informed judgments have a greater chance of achieving the desired goals of sustainability.

\section{Objectives}

- To identify the gaps between development sustainability and environmental mainstreaming.

- To describe the areas of profound attention needed to achieve environmental sustainability.

- To suggest possible remedies for sustainable development and environmental issues mainstreaming in Yasawa Island. 


\section{Methodology}

Mixed research approaches are to investigate and explore the different claims to address specific needs to develop and understand the complexity of a contextual phenomenon. Thus, this study employs both qualitative and quantitative parameters in an eclectic and pragmatic manner with a descriptive and exploratory analysis to draw some useful facts and information already available and make some critical evaluation.

Primary data:

Primary data is collected from a sample of 100randomly selected households from 5 villages from the district of Nacula.

\section{Secondary data:}

The secondary data is extracted from among different published sources such as International manuals and reports, magazines, voice and data Magazine, research articles, books and selected websites.

\section{Literature Review}

Erika Simpson (2016) talks about a millennium and sustainable development goals whereby some of the SDG goals are confusing and contradictory, lofty and immeasurable. Where the MDG's was meant for the developing countries only the SDG's are meant for all the countries. Everyone will need to design more and better solutions from global to local levels and we have to reinvent newer styles of consultation and decision making that improves global governance.

ParthaDasgupta (2013) talks about the orthodoxy around nature to be seen only as a form of productive capital and extends to integrate development and environmental thinking. By development, it should mean growth in wealth not only the Orthodox growth of GDP or growth of human development. Human ignorance to understanding the economic worth of natural capital is the barrier to understanding development. J.E. Vinuales (2013) talks about how sustainable development is turning brownish since it does not provide an adequate umbrella for the main challenges faced globally hence the need to use alternative ways to spearhead efforts to meet the implementation phase. The reason why previous efforts have deemed ineffective was due to the failure to garner government support.

Victoria Sutton (2005) talks about the newly enacted Fiji Environment Management Act which is the single most important recent effort to protect the natural resources of Fiji considering the methods of implementation in relation to the traditions and customs. Sustainable development and traditional and customary land tenure may not be compatible because individuals want to derive economic benefit immediately and directly. The Act focuses on people rather than environment and Fiji has contributed to the jurisprudence of customary law in its own jurisdiction.

\section{Demography Of The Respondents}

For the purpose of collecting primary data, a structured focus group interview was administered amongst 100 participants. Their opinion on sustainable, economical and ecological lifestyle changes adopted in the small island of Yasawa.The following is the demographic profile of the respondents.

\begin{tabular}{|l|l|r|r|}
\hline Particulars & Sub-Category & Frequency & Percentage \\
\hline Gender & Male & 50 & $50 \%$ \\
\hline & Female & 50 & $50 \%$ \\
\hline & Total & $\mathbf{1 0 0}$ & $\mathbf{1 0 0 . 0 0 \%}$ \\
\hline Age & $19-25$ Years & 15 & $15 \%$ \\
\hline & $26-35$ Years & 25 & $25 \%$ \\
\hline & $36-49$ Years & 10 & $10 \%$ \\
\hline & $50 \&$ Above & 50 & $50 \%$ \\
\hline Income & Total & $\mathbf{1 0 0}$ & $\mathbf{1 0 0 . 0 0 \%}$ \\
\hline \$1 FJD $=$ Rs30 & $\$ 10,000-\$ 15,000$ & 23 & $23 \%$ \\
\hline & $\$ 15,000-\$ 25,000$ & 52 & $52 \%$ \\
\hline & $\$ 25,000 \&$ Above & 25 & $25 \%$ \\
\hline
\end{tabular}

\section{Source: Field Survey}

The above table illustrates the demography of the 100 respondents that partake in the focus group interview. Out of the 100, respondent, 50 were male and 50 females from different age groups and income level. Out of 100 respondents, 15 are between 19-25 years, 25 are between 26-35 years, 10 between 36-49 years and finally the highest portion of respondents 50 are 50 years \& above. Sorting the respondents based on their 
income there are 23 respondents in the range of $\$ 10,000-\$ 15,000,52$ respondents in the group $\$ 15,000$ $\$ 25,000$ the highest portion of the respondents and 25 are in the group of $\$ 25,000$ and above per month.

\section{Results And Discussion}

Coastal areas are of vital importance to the societies of Fiji and for national development. Income from agriculture and tourism at Yasawa is directly tied to the condition and productivity of the shoreline features. The community is still heavily dependent on subsistence utilization of natural resources.

Agriculture - Sugar is still the backbone of the agricultural economy. The agricultural resources are managed in a way that maximizes resource owners and the community as a whole while ensuring conservation and protecting the environment.

Tourism- Tourism is mostly private sector driven and has grown significantly over the years and is the largest foreign exchange earner. The industry, however, has been significantly hampered by a political coup which however has improved and seen significant positive changes. The locals are mainly employed in unskilled and semi-skilled jobs and the skilled jobs are maintained by expatriates. The problem of unavailability of skilled labor stems from massive brain drain due to the military coup of 1987.

Culture - Fijian traditional way of organizing island life is becoming more challenging, and going forward sustainable development, which is a necessity, not a luxury. The vulnerability of the island lifestyle is becoming a leadership strength hence the government and general public have prioritized sustainability.Due to the nature of the islands being fragile and vulnerable, yet because of their size and present state of development, they have the greatest opportunity to demonstrate true and lasting sustainability. The Fijian sustainable development model is striving for a better stability and poise.

Environmental Impact Survey - Yearly an environmental impact survey is conducted at the resorts that allow the villagers to determine the impact the resort and guests have on the reef ecosystem since the island is one of the rare places with beautiful coral reefs, plants, and animals and various sea animals. The various eco-resorts blends the ecology with wonderful economic benefits for the local people. These -resorts are leading not just for the benefit of tourists or for profit but with an eco-prowess formula for sustainability.

Desalination Plant - The Yasawa region is one of Fiji's driest. Due to porous volcanic rock, there is no fresh water and limited bore water. The desalination plant converts salt water into drinking quality fresh water. The plant can produce up to 60,000 liters of fresh water every day.Sustainable development is not the only development that aims at quantitative improvement but also a qualitative improvement of the population. It is not only important to raise the standard of living of the people. People's perception towards each other and the environment should change as well.

\section{What Is Lacking In Policy Making}

The government should address economic, political and economic issues so that comprehensive and integrated strategies can be formulated. It is the lack of management and the priorities that today we face the problems of the world. Whether it is food or water- we do not lack them. Strategic collaboration is a necessity and global sustainable development can only be achieved through a close partnership between governments, the private business sector, and civil society together with people's participation in planning, equality of opportunities, and equitable growth are necessary for environmental sustainability.

\section{Conclusion}

For environmental protection to strike with growth consideration which is not necessarily a problem if development goals are laid out openly. The main issues that require attention are natural resource protection and management. New approaches can be taken to tackle both competing demands of environmental and development protection with some hard choices to be made. With increased awareness and willingness of all concerned in addressing the environmental issues, future sustainable development coupled with economic development is very much anticipated. Envirolnment plays an essential part /in development hence assimilation of the environment in all development planning is integral to achieving sustainable development. We all know that we have to protect the environment, whether through recycling or reuse as it's the primary concern of the future of humanity. The supply and demand market is consumerist in nature and our modern life requires a lot of resources every day. The problem lies as most people disagree what is and is not economically sound and how it affects businesses and jobs, however, every average person should do their bit as and when they can. For the interest of environmental sustainability at Yasawa Island knowing the core meaning of sustainability for the society gives a suitable action framing methodology which should be practical and strategically optimistic. A need to facilitate community involvement in decision and action integrating both long term and short terms economic and environmental sustainability. It requires a consistent and accurate framework to identify the most sustainable lifestyle and consumption and production pattern. Achieving economic and environmental sustainability requires considerable effort and austerity. That has to be based on acceptance by every individual 
and the need for lifestyle change coupled with the facilitative role of the government to turn the vicious cycle into a virtuous one.

\section{References}

[1] Dasgupta P. (2013) "The Nature of Economic Development and the Economic Development of Nature".

[2] Ganguly, J.B. Sustainable Human Development in the North-Eastern Region of India, Regency Publication, New Delhi, 1996, pp

[3] Iqbal M. (2006) "Environmental Law and Multilateral Environmental Agreements (MEAs) Environmental Management Tools a Training Manual, pp 75-82.

[4] Mebratu, D (1998) "Sustainability and Sustainable Development: Historical and Conceptual Review." Environmental Impact Assessment Review 18 pp 493-520.

[5] Simpson E. (2016) "Sustainable Development Goals Worth Sharing".

[6] Scott W and Gough S. (2003) "Sustainable development and learning: Framing the issues"pp 15-25.

[7] Sutton V. (2005) "Custom Tradition and Science in the South Pacific: Fijis New Environmental Management Act and Vanua" Journal of South Pacific Law, Vol. 9, No. 2.

[8] Sutton V (2005)“Custom, Tradition, and Science in the South Pacific: Fiji's New Environmental Management Act and Vanua".

[9] Vinuales J.E. (2013) "The Rise and Fall of Sustainable Development".

[10] http://www.nber.org/papers/w9597.pdf "The Kindergarten Rule of Sustainable Growth" retrieved 09/10/16.

[11] http://hdr.undp.org/statistics/data/Retrieved 13/10/16.

[12] http://www.environmentalscience.org/sustainabilityRetrieved 15/10/16.

Shobna Sabnam Hassan. "Trailing Appropriate Sustainable Development in Yasawa- Fiji Islands." IOSR Journal of Economics and Finance (IOSR-JEF) 8.4 (2017): 11-15. 